\title{
Mid- and late-Holocene shoreline changes along the southern coast of the Gulf of Finland
}

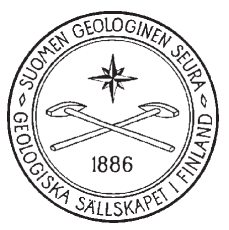

\author{
Ieva Grudzinska, Leili Saarse, Jüri VassiljeV \\ and AtKo Heinsalu \\ Institute of Geology at Tallinn University of Technology, \\ Ehitajate tee 5, 19086 Tallinn, Estonia
}

\begin{abstract}
In response to glacio-isostatic rebound in Estonia, a relative sea level fall occurred during the mid- and late-Holocene, and as a result, lowland regions in northern Estonia have experienced an evolution from sea to land. The mid- and late-Holocene shoreline changes along the southern coast of the Gulf of Finland were reconstructed, using litho-, bio- and chronostratigraphical proxies from four lakes. The lakes are located within the Gulf of Finland drainage system at different altitudes between 18 and $4 \mathrm{~m}$ above the present sea level. The isolation from the sea and the onset of freshwater lacustrine sedimentation occurred in Tänavjärv basin at 5400 cal yr BP, in Klooga basin at 4200 cal yr BP, in Lohja basin at 2200 cal yr BP and in Käsmu basin at 1800 cal yr BP. Through the application of GIS-based analysis, a modern digital terrain model and reconstructed past water level surfaces, we present a series of scenarios of shoreline and palaeogeography changes occurring since $7800 \mathrm{cal}$ yr BP. The land uplift rate, which was approximately $2.8 \mathrm{~mm}$

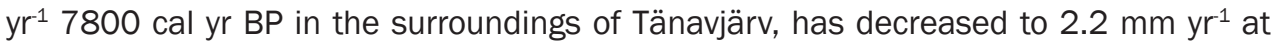
present and that at Lohja from 2.4 to ca $2.0 \mathrm{~mm} \mathrm{yr}^{-1}$, respectively. The relative sea level curves show a land uplift decrease, which is nearly linear since the mid-Holocene.
\end{abstract}

Keywords: lake sediments, stratigraphy, diatoms, absolute age, C-14, paleogeography, sea-level changes, Litorina Sea, Holocene, Estonia

Corresponding author email: ieva.grudzinska@gi.ee

Editorial handling: Joonas Virtasalo

\section{Introduction}

Since the deglaciation, the shoreline configuration around the Baltic Sea has been continuous, being controlled by the interaction between local glacioisostatic recovery and global eustatic sea level rise
(Björck, 1995). In Estonia, the latest research on shoreline displacement has been focused on the earliest stages of the Baltic Sea, i.e. the development of the Baltic Ice Lake (Vassiljev et al., 2011; Vassiljev 
\& Saarse, 2013), Yoldia Sea (Heinsalu \& Veski, 2007), Ancylus Lake (Saarse et al., 1999) and Litorina Sea (Saarse et al., 2009, 2010). However, the shoreline development after the Litorina Sea transgression, which formed a comparatively well developed and therefore easily traceable beach formation on the southern coast of the Gulf of Finland, is considerably poorly studied, many disputable aspects exist and the current data are not always consistent with the results from the neighbouring areas (Miettinen, 2002; Sandgren et al., 2004; Miettinen et al., 2007).

Ramsay (1929) was the first, who described the Litorina Sea beach formations at 53 different locations in Estonia and reconstructed its isobases, which are valid up to the present. Kents (1939) distinguished the Litorina Sea shorelines at five different levels, compiled a shoreline diagram and suggested the uplift gradient $15.5 \mathrm{~cm}$ $\mathrm{km}^{-1}$ for the Litorina Sea, which has been accepted by many later researches (e.g., Kessel \& Raukas, 1967). Detailed studies on the post-Litorina sea level changes are highly limited and the shoreline changes for this time window are poorly constrained. To overcome this problem, we studied four basins, using the isolation method that is widely utilised in sea level reconstructions (e.g., Lindén et al., 2006; Miettinen et al., 2007; Lunkka et al., 2012; Saarnisto, 2012).

The main objectives of the current work are to study mid-and late-Holocene shoreline changes in northern Estonia by providing the chronological control on relative sea level changes. Therefore a series of emerged coastal lakes, situated at various elevations between the Litorina Sea transgression limit and the present sea level, were investigated. We also aimed at reconstructing the local palaeogeography, compiling a relative sea level curve and testing the existing agedepth models (Saarse et al., 2007; Rosentau et al., 2011), which claims that the sea level has regressed rather evenly over the last 5000 years due to a linear land uplift (Mörner, 1979; Lindén et al., 2006).

\section{Site descriptions}

The studied lakes Tänavjärv, Klooga, Lohja and Käsmu are located in northern and northwestern Estonia (Fig. 1), on the terraces of the Litorina and Limnea Sea at 18.4 and $3.9 \mathrm{~m}$ above the present sea level (a.s.l.), respectively (Table 1 ). The glacial

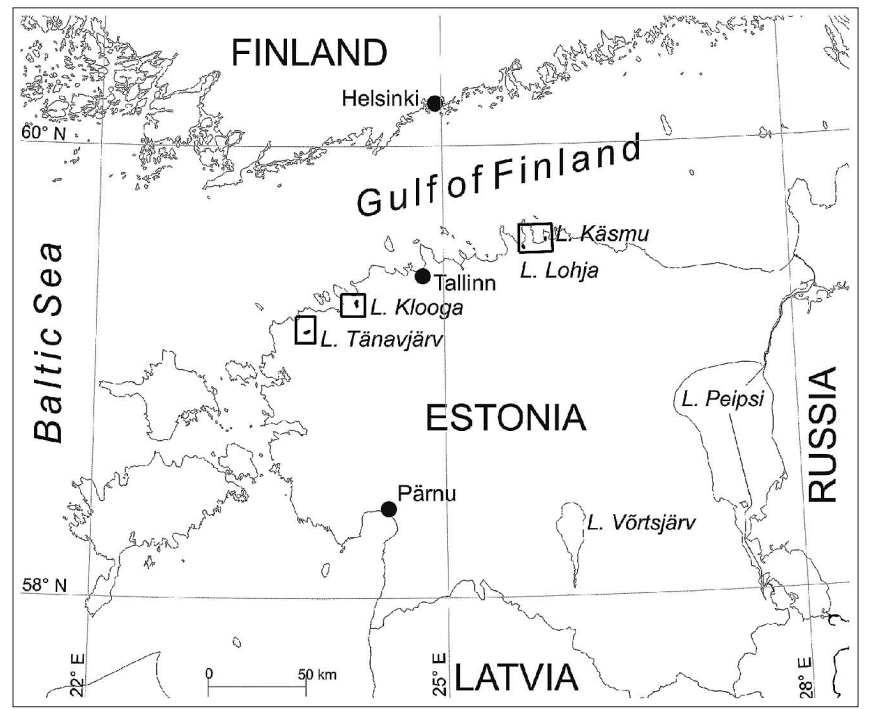

Fig. 1. Location of the studied lakes in northern Estonia, showing the positions of the palaeogeographic maps in Figs. 4-6.

Table 1. Morphometric characteristics of the studied lakes.

\begin{tabular}{llllllll} 
Site & $\begin{array}{c}\text { Latitude } \\
\mathrm{N}\end{array}$ & $\begin{array}{c}\text { Longitude } \\
\mathrm{E}\end{array}$ & $\begin{array}{l}\text { Area } \\
(\mathrm{ha})\end{array}$ & $\begin{array}{l}\text { Water } \\
\text { depth }(\mathrm{m})\end{array}$ & $\begin{array}{l}\text { Altitude } \\
(\mathrm{m} \text { a.s.l.) }\end{array}$ & $\begin{array}{l}\text { Catchment } \\
\text { area }\left(\mathrm{km}^{2}\right)\end{array}$ & $\begin{array}{l}\text { Threshold } \\
(\mathrm{m} \text { a.s.I. })\end{array}$ \\
\hline Lake Tänaviärv & $59^{\circ} 10^{\prime} 54^{\prime \prime}$ & $23^{\circ} 48^{\prime} 42^{\prime \prime}$ & 138.8 & 3.0 & 18.4 & 4.7 & 17.4 \\
Lake Klooga & $59^{\circ} 18^{\prime} 30^{\prime \prime}$ & $24^{\circ} 13^{\prime} 57^{\prime \prime}$ & 131.4 & 2.5 & 11.8 & 5.8 & 11.8 \\
Lake Lohja & $59^{\circ} 32^{\prime} 57^{\prime \prime}$ & $25^{\circ} 41^{\prime} 23^{\prime \prime}$ & 56.8 & 3.7 & 5.5 & 12.3 & 6.0 \\
Lake Käsmu & $59^{\circ} 34^{\prime} 56^{\prime \prime}$ & $25^{\circ} 52^{\prime} 51^{\prime \prime}$ & 48.5 & 3.3 & 3.9 & 16.5 & 4.5
\end{tabular}


deposits covered by marine and aeolian sediments are rather thin, except in buried valleys, where they reach 37-46 m (Kadastik \& Ploom, 2000). The relatively flat topography with gentle sloping towards the sea resulted in extensive formation of peat around the investigated lake basins. During the Litorina Sea transgression, all the studied lake basins were inundated by sea water, as the maximum shorelines of the Litorina Sea are recorded at 22.1 $\mathrm{m}$ a.s.l. at Tänavjärv, $21.9 \mathrm{~m}$ a.s.l. at Klooga, 18.8 $\mathrm{m}$ a.s.l. at Lohja and $17.7 \mathrm{~m}$ a.s.l. at Käsmu.

Lake Tänavjärv (water level $18.4 \mathrm{~m}$ a.s.l., threshold $17.4 \mathrm{~m}$ a.s.l.) is an elongated shallow, medium-size semidystrophic lake. The original threshold is located in the southern shore of the lake and is buried under the peat. Prior to AD 1934, Tänavjärv had an outlet to Lake Veskijärv, its area was smaller and water table was lower, (17.9 $\mathrm{m}$ a.s.l.; Riikoja, 1934) than at present (Table 1). A ditch between lakes Tänavjärv and Veskijärv has grown over, and consequently, the lake level has been raised about $0.5 \mathrm{~m}$. A set of small beach ridges and dunes has been recognised at $19-21 \mathrm{~m}$ a.s.l. in the north and northwest of the lake. The shores of the lake are peaty and partly sandy in the west and east. The catchment is forested by boreal tree species, mostly by Pinus sylvestris, and frequently suffers from forest fires (Kangur, 2005).

Lake Klooga (water level and threshold $11.8 \mathrm{~m}$ a.s.l.) is located in a north-south oriented depression on the border of the Lahepera-Kloogaranna buried valley (Kadastik \& Ploom, 2000) and Pakri klint headland. The lake is surrounded by abraded limestone terraces and a chain of gravelly beach ridges at $22-20 \mathrm{~m}$ a.s.l. in the east, dunes in the north and peatland in the west and south (Tammekann, 1940). Lake Klooga is a shallow drainage lake, largely overgrown by emergent aquatic macrophytes. Due to the overabundance of the macrophyte stand, the lake area has decreased to 7 ha over the last 70 years. Small brooks and bottom springs carry calcareous water to the lake and promote precipitation of lacustrine lime. A ditch outflowing to the Vasalemma River is temporarily dry. The western and southern part of the catchment is paludified and forested; the eastern part is covered by fields and meadows, the northern part by a pine forest. The bottom of the lake is covered by gyttja, calcareous gyttja and silty gyttja with the maximum thickness of $4.5 \mathrm{~m}$ in the central part of the basin.

Lake Lohja (water level $5.5 \mathrm{~m}$ a.s.l., threshold $6.0 \mathrm{~m}$ a.s.1.) is located in a wide Valgejōe-Loobu klint bay which is entirely filled up with sand (Tammekann, 1940). The well-shaped Ancylus Lake beach ridges have formed an arc $2 \mathrm{~km}$ to the south of Lake Lohja, while chains of the Litorina Sea and Limnea Sea beach ridges and dunes, which are parallel to the shoreline, occur in low-lying places. The upper limit of the inner beach ridge lies at $9 \mathrm{~m}$ in the west and at $8 \mathrm{~m}$ a.s.l. in the north. Lake Lohja is a dark-coloured lake with an outflow brook to the Hara Bay.

Lake Käsmu (water level 3.9 m a.s.l., threshold $4.5 \mathrm{~m}$ a.s.l.) is located on the Käsmu Peninsula and is a drainage lake with water that is highly rich in nutrients (Table 1). The lake is bordered by beach ridges at $8 \mathrm{~m}$ a.s.l. in the west and a slightly paludified marine plain in the east, covered by different types of boreal forest. The transgressional beach ridges of Ancylus Lake and the Litorina Sea run $2-3 \mathrm{~km}$ to the south of the lake. The water level of Lake Käsmu is regulated.

\section{Material and methods}

A series of overlapping cores were obtained with a Russian peat sampler from the deepest parts of the basins. 1-m-long core sections were described in field, photographed, sealed in plastic liners and transported to the laboratory and stored in a coldroom. The organic matter $(\mathrm{OM})$ content was quantified by loss-on-ignition (LOI) at $525^{\circ} \mathrm{C}$. The carbonate content was estimated in terms of the difference between LOI at $900{ }^{\circ} \mathrm{C}$ and $525^{\circ} \mathrm{C}$ multiplied by 1.36 . The ignition residue was estimated as mineral matter content. Magnetic susceptibility (MS) was measured with a Bartington MS2E high-resolution scanning sensor from the sediment surface at $1 \mathrm{~cm}$ resolution.

Diatom analyses from Lake Tänavjärv (Saarse et al., 1989) and from Lake Käsmu (Kessel et al., 1986) were made by E. Vishnevskaya several years 
ago. For this data, diatom taxonomy was modified, diagrams were redrawn and sediment sequences were correlated on the basis of lithostratigraphy and LOI results. For the other sediment records the diatom preparation followed techniques described in Battarbee et al. (2001). Diatom samples were digested in hydrogen peroxide until all $\mathrm{OM}$ was removed, hydrochloric acid was added to remove carbonates, and repeated decantation was applied to extract fine and coarse mineral particles. Some drops of the remaining residue were spread over the cover slip, dried overnight and mounted permanently onto microscope slides, using Naphrax medium. At least 400 diatom valves were counted from each subsample under Zeiss Axio Imager A1 microscope at $\times 1000$ magnification and identified to species level. Diatoms were grouped according to their salinity tolerance into brackish/marine, halophilous and freshwater taxa, and according to their habitat into plankton and periphyton. Diatom floras used for the identification and the ecological information were based on the work by Krammer \& LangeBertalot (1986, 1988, 1991a, 1991b), Witkowski et al. (2000), Snoeijs (1993), Snoeijs \& Vilbaste (1994), Snoeijs \& Potapova (1995), Snoeijs \& Kasperovičien (1996), Snoeijs \& Balashova (1998). Sediment LOI and MS, as well as diatom results were plotted, using the TGView software (Grimm, 2007).

The radiocarbon dating of macrofossils was performed partly in the Poznan Radiocarbon Laboratory (AMS dates), partly in the Institute of Geology at Tallinn University of Technology (conventional dates). The chronology of the studied sediment sequences is based on the calibration of the radiocarbon dates, using the IntCal09 calibration dataset (Reimer et al., 2009) and the OxCal 4.1 program (Bronk Ramsey, 2009). Radiocarbon dates and lithological data were combined, using the OxCal deposition model (Bronk Ramsey, 2008). In the present study the calibrated ages (cal yr BP) are provided as weighted averages with 2 sigma. Due to the low level of salinity in the Gulf of Finland (Eronen et al., 2001; Miettinen et al., 2007), the reservoir effect in the coastal sediment of Estonia has not been considered. At the same time, results from an archipelago not far from Stockholm show reservoir ages between 1100 and 400 years (Hedenström \& Possnert, 2001), commonly assumed to be in the range of 200 and 400 years (Risberg et al., 2005). The latest studies confirm not only the spatial, but also the temporal difference in the reservoir age since the Litorina Sea (Lougheed et al., 2012).

Palaeogeographical reconstructions are based on GIS analysis in which interpolated water level surfaces were removed from the digital terrain model (DTM; Rosentau et al., 2009). Topographic maps on scales of 1:10 000 and 1:25 000 were used to create a DTM with grid sizes $15 \times 15 \mathrm{~m}$ (Tänavjärv, Klooga) and $20 \times 20 \mathrm{~m}$ (Lohja, Käsmu). The peat deposits were removed from the DTM, using soil maps on a scale of 1:10 000, whereas the data on peat thickness were obtained from different sources. For the purpose of constructing the relative sea level curve, additional materials from several isolation basins, such as radiocarbon dates and morphometrical data on the raised beaches, were considered (Table 2).

\section{Results and discussion}

\subsection{Environmental conditions}

The diatom analysis applied in this study proved to be an effective tool in identifying the position of the isolation contact in the sediment sequence and in defining the related changes in basin salinity and isolation dynamics. The succession of diatom assemblages distinctly records palaeoenvironmental changes induced by the glacio-isostatic uplift and consecutive relative sea level regression through periods of brackish-water environment, isolation from the sea and subsequent lacustrine conditions.

Lake Tänavjärv sediment comprises sand (Tä1), silt with dispersed OM (Tä-2), silty gyttja (Tä3) and gyttja (Tä-4; Table 3), and their LOI results are displayed in Figure 2A. MS values are low, even in the silt. Silt with plant remains in core depth between 347 and $342 \mathrm{~cm}$ was deposited about 5700-5600 cal yr BP. The basal pre-isolation sediment of the Tänavjärv basin is characterised by 
Table 2. Radiocarbon dates considered for the reconstruction of the relative sea level curve.

\begin{tabular}{|c|c|c|c|c|c|c|c|}
\hline Site & $\begin{array}{l}\text { Basin } \\
\text { altitude } \\
\text { (m a.s.l.) }\end{array}$ & Depth $(\mathrm{cm})$ & ${ }^{14} \mathrm{C}$ date & $\begin{array}{l}\text { Calibrated } \\
\text { age range, BP } \\
\text { (weighted } \\
\text { average) }\end{array}$ & $\begin{array}{l}\text { Laboratory } \\
\text { ID }\end{array}$ & $\begin{array}{l}\text { Dated } \\
\text { material }\end{array}$ & Reference \\
\hline Tänaviärv & 18.4 & $316-321$ & $4490 \pm 70$ & $\begin{array}{l}4920-5310 \\
(5130 \pm 100)\end{array}$ & Tln-3306 & Gyttja, bulk & Current study \\
\hline Tänaviärv & 18.4 & $321-324$ & $4600 \pm 100$ & $\begin{array}{l}5050-5450 \\
(5270 \pm 110)\end{array}$ & Tln-3305 & Silty gyttja, bulk & Current study \\
\hline Tänaviärv & 18.4 & $342-347$ & $4930 \pm 40$ & $\begin{array}{l}5600-5730 \\
(5660 \pm 40)\end{array}$ & Poz-42173 & Woody pieces & Current study \\
\hline Klooga & 11.8 & $335-340$ & $3760 \pm 40$ & $\begin{array}{l}3990-4230 \\
(4110 \pm 60)\end{array}$ & Poz-42168 & $\begin{array}{l}\text { Terrestrial } \\
\text { macro remains }\end{array}$ & Current study \\
\hline Klooga & 11.8 & $390-395$ & $3840 \pm 50$ & $\begin{array}{l}4150-4420 \\
(4280 \pm 80)\end{array}$ & Poz-42169 & $\begin{array}{l}\text { Terrestrial } \\
\text { macro remains }\end{array}$ & Current study \\
\hline Lohia & 5.8 & $365-370$ & $2280 \pm 30$ & $\begin{array}{l}2160-2350 \\
(2270 \pm 60)\end{array}$ & Poz-42171 & Pinus bark & Current study \\
\hline Lohia & 5.8 & 395 & $2490 \pm 35$ & $\begin{array}{l}2440-2730 \\
(2580 \pm 80)\end{array}$ & Poz-42172 & Tilia wood & Current study \\
\hline Käsmu & 3.9 & 416 & $1830 \pm 30$ & $\begin{array}{l}1700-1860 \\
(1770 \pm 40)\end{array}$ & Poz-42177 & Pinus bark & Current study \\
\hline Käsmu & 3.9 & 433 & $1910 \pm 30$ & $\begin{array}{l}1790-1930 \\
(1860 \pm 30)\end{array}$ & Poz-42166 & Pinus wood & Current study \\
\hline Aabla & 24 & $545-555$ & $7250 \pm 80$ & $\begin{array}{l}7940-8280 \\
(8080 \pm 80)\end{array}$ & Tln-3195 & $\begin{array}{l}\text { Coarse detritus } \\
\text { gyttja, bulk }\end{array}$ & $\begin{array}{l}\text { Saarse et al., } \\
2010\end{array}$ \\
\hline Aabla & 24 & 556 & $7280 \pm 50$ & $\begin{array}{l}7990-8190 \\
(8090 \pm 50)\end{array}$ & Poz-33490 & Piece of wood & $\begin{array}{l}\text { Saarse et al., } \\
2010\end{array}$ \\
\hline Aabla & 24 & $570-572$ & $6920 \pm 40$ & $\begin{array}{l}7670-7840 \\
(7750 \pm 50)\end{array}$ & Poz-35465 & Sand with $O M$ & $\begin{array}{l}\text { Saarse et al., } \\
2010\end{array}$ \\
\hline Maarikoja & $16.8-17.3$ & & $6820 \pm 70$ & $\begin{array}{l}7570-7830 \\
(7670 \pm 70)\end{array}$ & Tln-200 & $\begin{array}{l}\text { Buried Carex- } \\
\text { Phragmites peat }\end{array}$ & $\begin{array}{l}\text { Kessel \& } \\
\text { Linkrus, } 1979\end{array}$ \\
\hline Maarikoja & $16.8-17.3$ & & $7240 \pm 90$ & $\begin{array}{l}7870-8300 \\
(8070 \pm 90)\end{array}$ & Tln-201 & Wood & $\begin{array}{l}\text { Kessel \& } \\
\text { Linkrus, } 1979\end{array}$ \\
\hline Vääna & 24.7 & 201.5 & $6240 \pm 40$ & $\begin{array}{l}7070-7270 \\
(7200 \pm 50)\end{array}$ & Poz-24245 & Plant remains & $\begin{array}{l}\text { Saarse et al., } \\
2009\end{array}$ \\
\hline Vääna & 24.7 & $220-221$ & $7420 \pm 40$ & $\begin{array}{l}8170-8340 \\
(8250 \pm 50)\end{array}$ & Poz-24267 & Plant remains & $\begin{array}{l}\text { Saarse et al., } \\
2009\end{array}$ \\
\hline Niitvälja & 19.5 & $280-290$ & $7580 \pm 70$ & $\begin{array}{l}8210-8540 \\
(8390 \pm 70)\end{array}$ & Tln-261 & Buried gyttja, bulk & $\begin{array}{l}\text { Punning et al., } \\
1980\end{array}$ \\
\hline
\end{tabular}

floristic heterogeneity, mixed occurrence of marine and brackish-water species with relatively frequent freshwater forms (Fig. 3A). The dominant part of the assemblage, however, consists of periphytic saline water tolerant species, while euplanktonic forms are absent. Periphytic brackish/marine diatoms, namely Diploneis didyma, Cocconeis scutellum, Hyalodiscus scoticus and Campylodiscus clypeus are the diatoms that are most abundant in the silt layer, accounting for $60-80 \%$ of the assemblage (Fig. 3A). This diatom evidence is most likely an indication of a sediment accumulation in a shallow-water lagoon, rather than in an open-sea environment. According to radiocarbon dates, the lagoonal phase of the basin lasted for at least 400 years.

The distinct change in the diatom composition from brackish to freshwater species and sediment lithostratigraphy from silty gyttja to gyttja at the core depth of $327 \mathrm{~cm}$ indicates the isolation event. The modelled age of the isolation is $5420 \pm 130 \mathrm{cal}$ 

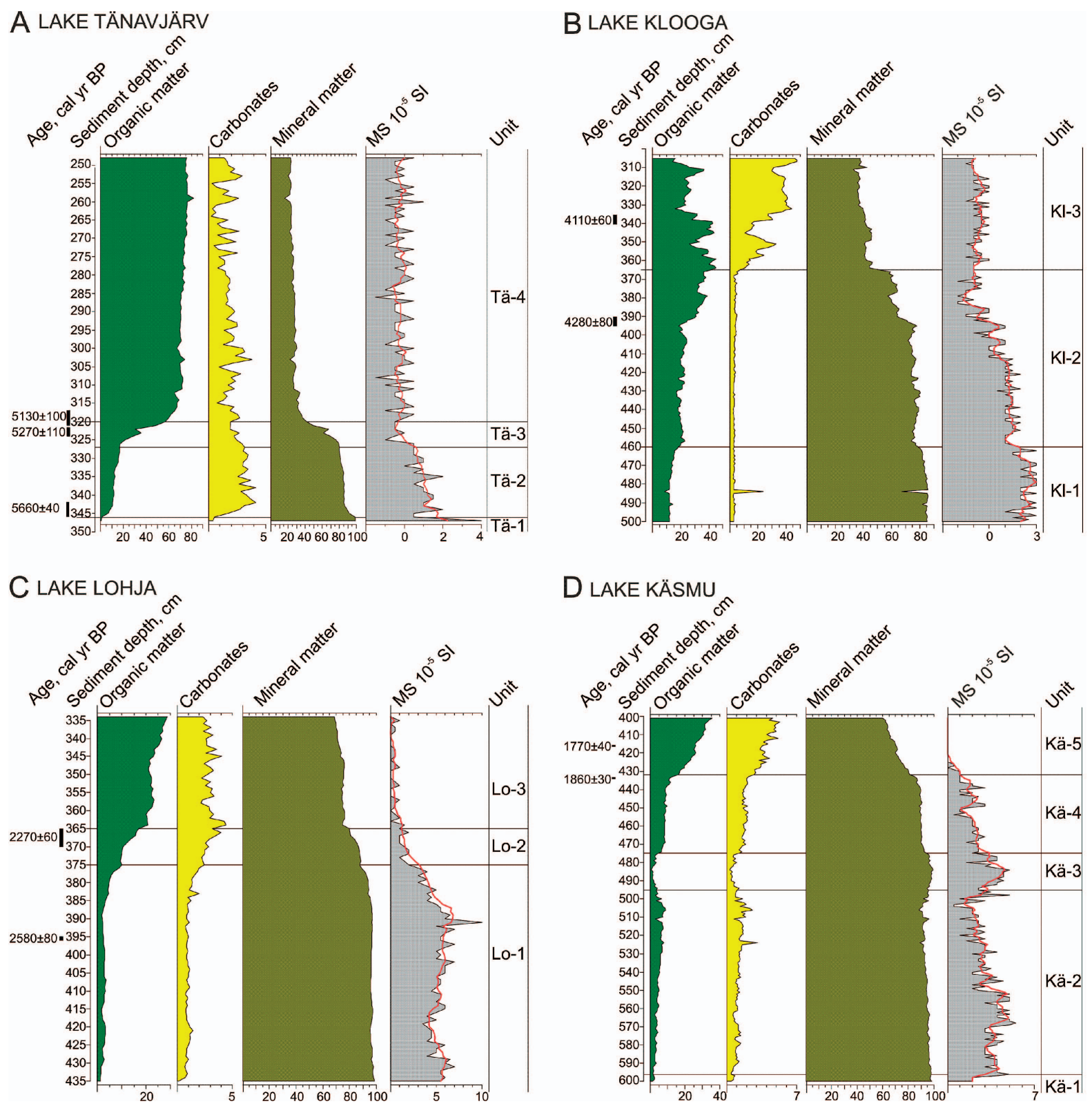

Fig. 2. Sediment organic matter, carbonates and mineral matter content estimated by loss-on-ignition (\% of dry weight) and magnetic susceptibility (MS) of Lake Tänavjärv (A), Lake Klooga (B), Lake Lohja (C) and Lake Käsmu (D). The red line in the MS curve is 5-sample moving average.

yr BP (hereafter $5400 \mathrm{cal} \mathrm{yr} \mathrm{BP).} \mathrm{Above} \mathrm{the} \mathrm{isolation}$ level brackish/marine diatoms disappear, the halophilous taxa decreases and the freshwater taxa, such as Navicula radiosa, Stauroneis phoenicenteron, Sellaphora pupula and Cymbopleura naviculiformis increases. The isolation from the sea was probably a rather short-term process.
Initially, the water in the post-isolated basin was rather nutrient rich, confirmed by benthic diatoms such as Navicula radiosa and Sellaphora pupula. However, the final takeover of diatoms such as Pinnularia spp., Brachysira serians, Eunotia spp. and Tabellaria fenestrata implies that the lake underwent a rapid change from alkaline to acidic nutrient-poor 
Table 3. Lithostratigraphy of the studied sediment cores.

\begin{tabular}{|c|c|c|c|}
\hline Site & Depth, $\mathrm{cm}$ & Sediment description & Unit \\
\hline Lake Tänavjärv & $\begin{array}{l}245-320 \\
320-327 \\
327-347 \\
347-350+\end{array}$ & $\begin{array}{l}\text { Gyttia, dark brown, slightly consolidated } \\
\text { Silty gyttia, dark grey, limit with gyttia sharp } \\
\text { Silt with dispersed OM, dark grey } \\
\text { Sand, fine grained, light grey }\end{array}$ & $\begin{array}{l}\text { Tä-4 } \\
\text { Tä-3 } \\
\text { Tä-2 } \\
\text { Tä-1 }\end{array}$ \\
\hline Lake Klooga & $\begin{array}{l}300-365 \\
365-460 \\
460-500+\end{array}$ & $\begin{array}{l}\text { Calcareous gyttia, beige, subfossil mollusc shells, fluctuating } O M \\
\text { Silty gyttia, dark brown, well decomposed } O M \\
\text { Silt with dispersed OM }\end{array}$ & $\begin{array}{l}\mathrm{KI}-3 \\
\mathrm{KI}-2 \\
\mathrm{KI}-1\end{array}$ \\
\hline Lake Lohja & $\begin{array}{l}333-364 \\
364-375 \\
375-435+\end{array}$ & $\begin{array}{l}\text { Gyttia, brown, loose } \\
\text { Silty gyttia, greenish grey, at } 363 \mathrm{~cm} \text { richly plant remains } \\
\text { Silt, grey dispersed OM }\end{array}$ & $\begin{array}{l}\text { Lo-3 } \\
\text { Lo-2 } \\
\text { Lo- } 1\end{array}$ \\
\hline Lake Käsmu & $\begin{array}{l}400-433 \\
433-475 \\
475-495 \\
495-595 \\
595-600+\end{array}$ & $\begin{array}{l}\text { Gyttia, dark brown, soft } \\
\text { Silt with OM, dark grey } \\
\text { Sand, medium size, at lower limit thin OM rich layer } \\
\text { Silt with sparse plant remains, dark grey } \\
\text { Sand, fine grained, grey }\end{array}$ & $\begin{array}{l}\text { Kä-5 } \\
\text { Kä-4 } \\
\text { Kä-3 } \\
\text { Kä-2 } \\
\text { Kä-1 }\end{array}$ \\
\hline
\end{tabular}

conditions (Bigler et al., 2000; Dixit \& Dickman, 1986) due to paludification of the catchment.

Lake Klooga sediment lithology differs from that of Lake Tänavjärv, containing more $\mathrm{OM}$ rich silt (Kl-1) and silty gyttja $(\mathrm{Kl}-2)$ that grades into calcareous gyttja (Kl-3; Table 3). The OM content peaks in the upper part of silty gyttja $(\mathrm{Kl}-2)$ and lower part of calcareous gyttja (Kl-3; Fig. 2B). The shift in the MS values in general coincides with sediment lithostratigraphical boundaries and is associated with decrease in mineral matter. The calcareous gyttja that terminates the sediment sequence is characterised by low MS values (Fig. 2B). Silty gyttja in the basal part of the sediment sequence $(420-365 \mathrm{~cm})$ contains periphytic brackish/marine diatoms, namely Achnanthes fogedii, Campylodiscus clypeus, Planothidium delicatulum and Karayevia submarina, periphytic halophilous taxa, such as Epithemia turgida, E. sorex, Hippodonta hungarica and Cocconeis placentula, and small-sized fragilarioid species with brackish water affinity, such as Pseudostaurosiropsis geocollegarum, Pseudostaurosira elliptica and Opephora mutabilis (Fig. 3B). The diatom assemblage suggests brackish water environment, and the AMS ${ }^{14} \mathrm{C}$ dating yielding the age of $4280 \pm 80 \mathrm{cal} \mathrm{yr}$ BP consequently indicates the period when the basin had been a semi-closed lagoon with a connection to the open sea.

In the interval between $365-350 \mathrm{~cm}$, cosmopolite salinity-indifferent Fragilaria spp. predominate after the disappearance of the brackishwater diatom assemblage. Small-sized fragilarioid taxa are considered to be the pioneer diatoms that have an advantage in a rapidly changing environment (Yu et al., 2004) and thus the peak of Fragilaria spp. is regarded as the marker of the transition to the final isolation of the Klooga basin. A dominance of periphytic freshwater diatoms, such as Cymbellafalsa diluviana, Sellaphora vitabunda and Achnanthidium minutissimum from the core-depth of $345 \mathrm{~cm}$ indicates the isolation from the sea and suggests a shallow hard-water lake environment. An AMS ${ }^{14} \mathrm{C}$ age of $4110 \pm 60 \mathrm{cal}$ yr BP corresponds to the time shortly following the isolation and the modelled age of isolation is $4180 \pm 50 \mathrm{cal} \mathrm{yr} \mathrm{BP}$ (hereafter $4200 \mathrm{cal} \mathrm{yr} \mathrm{BP).}$

Lake Lohja lithostratigraphy follows the transition from silt (Lo-1) to silty gyttja (Lo-2) and to gyttja (Lo-3; Table 3). The MS of the sequence is rather stable between the core depths of 435 and $390 \mathrm{~cm}$, decreasing successively between 390 and $360 \mathrm{~cm}$ and stabilising in the upper part at low values (Fig. 2C).

The basal part of the core $(400-365 \mathrm{~cm})$ shows 

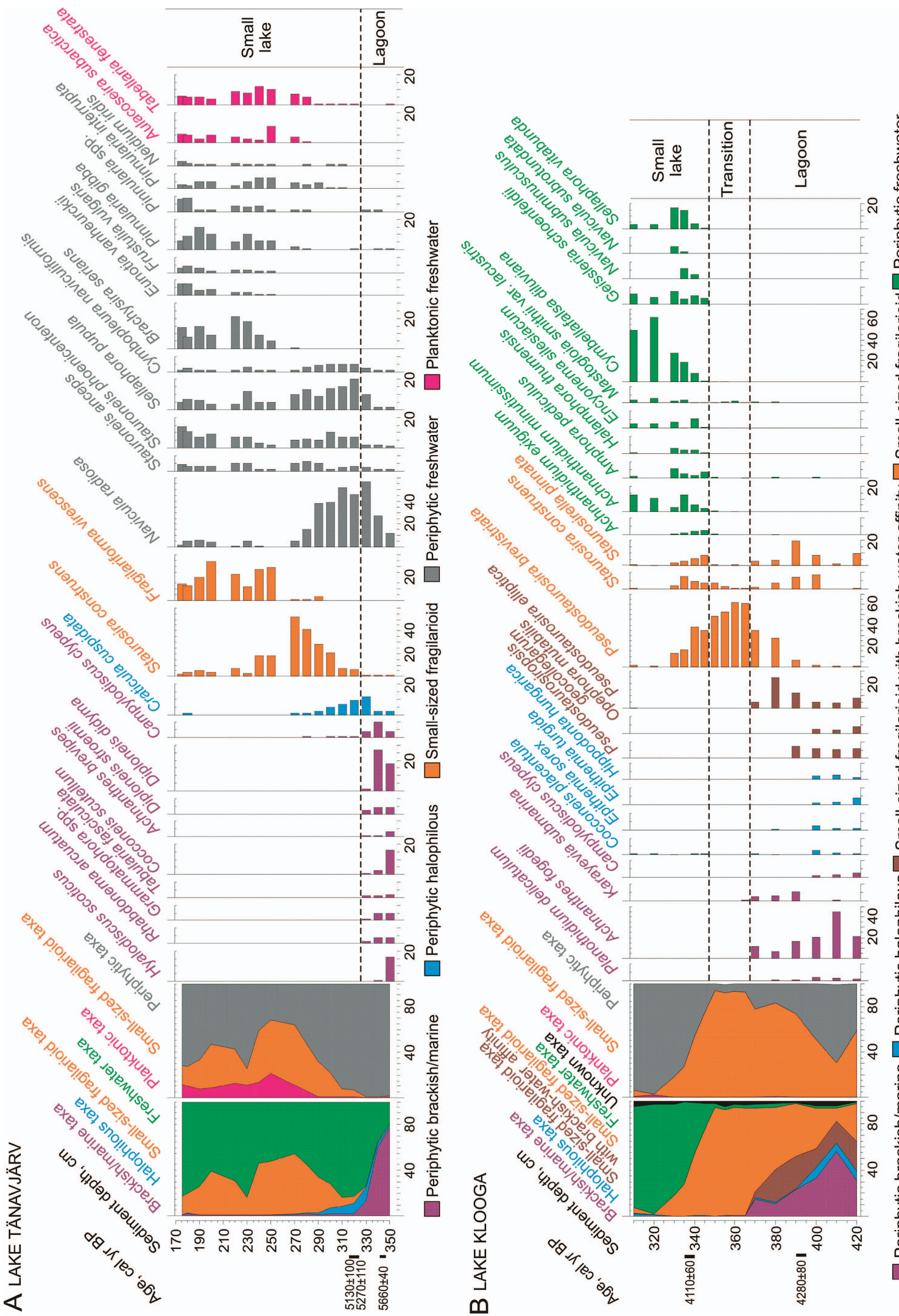

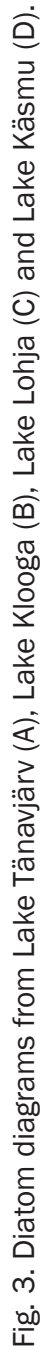



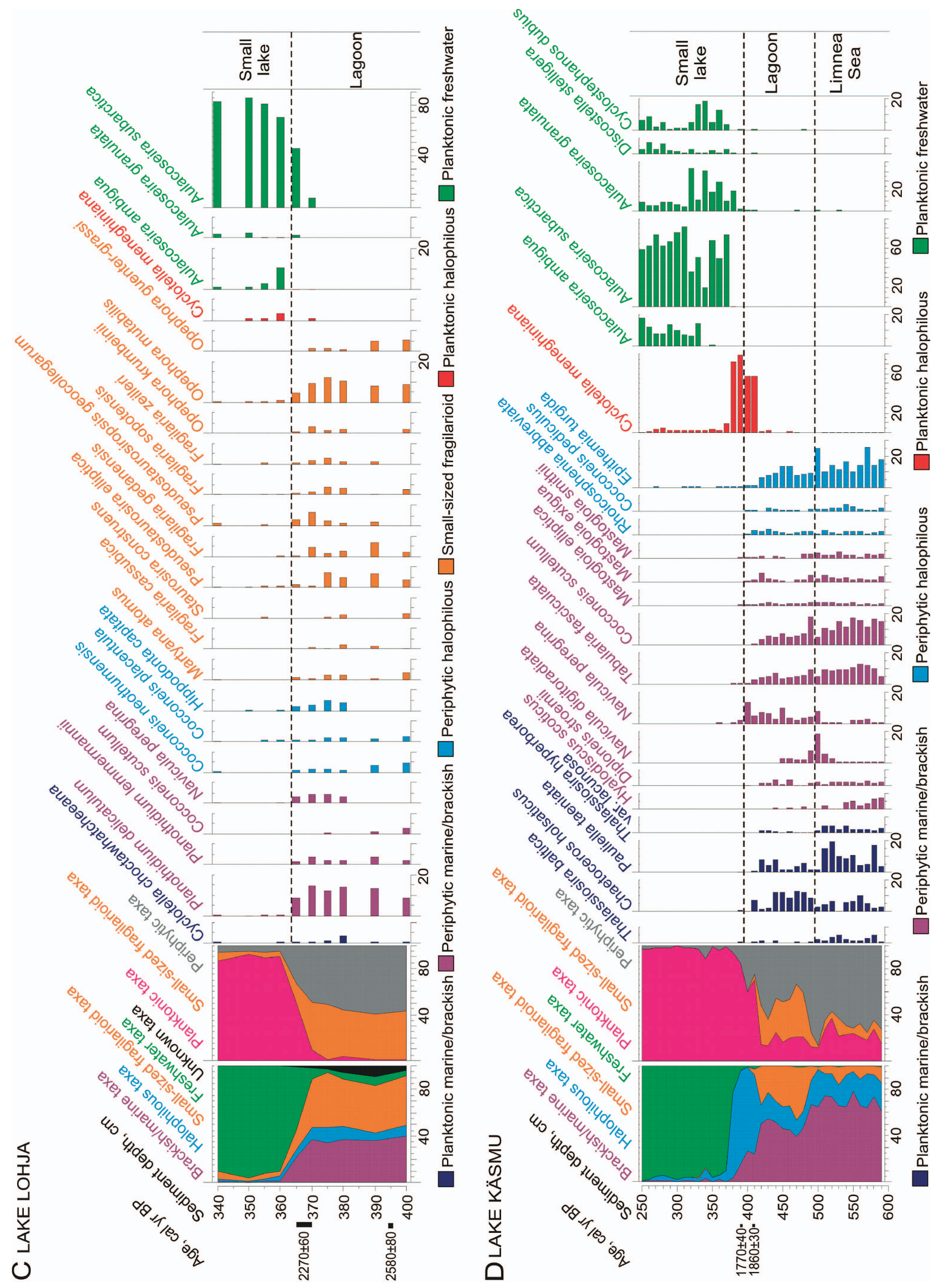
high values of benthic brackish/marine diatoms, notably Planothidium delicatulum (Fig. 3C). Simultaneously, small-sized fragilarioid epipsammic diatoms with brackish-water affinity, such as Opephora mutabilis, O. guentergrassi and Fragilaria gedanensis are abundant. At the core depth of $360 \mathrm{~cm}$ brackish/marine diatoms have declined and planktonic freshwater diatom Aulacoseira subarctica predominates together with $A$. ambigua and $A$. granulata, implying a relatively abrupt isolation. An AMS radiocarbon date of $2270 \pm 60 \mathrm{cal} \mathrm{yr} \mathrm{BP,}$ obtained from a pine bark fragment, represents the date that immediately precedes the isolation, and the modelled age of isolation is $2230 \pm 70 \mathrm{cal} \mathrm{yr} \mathrm{BP}$ (hereafter $2200 \mathrm{cal} \mathrm{yr} \mathrm{BP).}$

Post-isolation sediments are characterised by the predominance of planktonic freshwater Aulacoseira species. The most common diatom Aulacoseira subarctica is meroplanktonic and is only present in the water column when there is sufficient turbulence (Gibson et al., 2003), therefore the distinct increase in planktonic diatoms is not related to the lake level rise, but can instead be explained by the location in an open landscape close to a windy sea coast (Grudzinska et al., 2012), where the exposure to wind-induced waves resulted in the turbulent mixing of the water column.

Lake Käsmu lithostratigraphy is rather similar to Lohja site, however, the Käsmu core also includes a sand layer (Kä-3), imbedded into silt (Kä-2, Kä4; Table 3). The MS shows a wiggly appearance throughout the lithostratigraphical units (Fig. 2D). The diatom composition at the base of the core includes mainly diatoms with marine and brackishwater affinity (Fig. 3D), such as pelagic Chaetoceros holsaticus, Pauliella taeniata and Thalassiosira baltica, as well as periphytic Cocconeis scutellum and Tabularia fasciculata, indicating rather open bay-like conditions with brackish-water environment. The diatom-derived isolation at the depth of $400 \mathrm{~cm}$ is marked by a decline in brackish-water diatoms and dominance of freshwater planktonic Aulacoseira taxa, reflecting the development of a small eutrophic lake. The modelled age of isolation is $1840 \pm 30 \mathrm{cal}$ yr BP (hereafter $1800 \mathrm{cal}$ yr BP). The high abundance of planktonic Cyclotella meneghiniana at the biostratigraphic isolation contact is an interesting feature. A peak of $C$. meneghiniana that grows in variable environmental conditions: in brackish waters with elevated nutrient concentration (Weckström \& Juggins, 2006), lakes with high conductivity (Saros \& Fritz, 2000) or hypereutrophic lakes (Bradshaw et al., 2002) presumably suggests highly elevated water conductivity and nutrient concentrations during the final isolation event.

\subsection{Palaeogeography}

Based on the results of the current study, several palaeogeographical maps were constructed, which correspond to the following time windows: for Tänavjärv area 6500, 6000 and $5400 \mathrm{cal} \mathrm{yr} \mathrm{BP;} \mathrm{for}$ Klooga area 7800, 4500 and $4000 \mathrm{cal} \mathrm{yr} \mathrm{BP;} \mathrm{for}$ Lohja and Käsmu area 7800, 2200 and $1800 \mathrm{cal} \mathrm{yr}$ BP (Figs. 4-6). During the peak of the Litorina Sea transgression about $7800 \mathrm{cal}$ yr BP, numerous beach ridge systems formed along an ancient coastline, stretching continuously in the North Estonian klint bays as a well-developed beach ridge arc at $21 \mathrm{~m}$ a.s.1. $15 \mathrm{~km}$ SE from Tänavjärv and a ridge system at about $17.5 \mathrm{~m}$ a.s.1. $2.5 \mathrm{~km}$ to the south from Käsmu. At that time only small islets emerged not far from the studied lake basins that were fully inundated by the sea.

The development and isolation of Lake Tänavjärv was determined by the Audevälja-Harju-Risti-Pedase buried endmoraine ridge and a glaciofluvial delta sediment reaching up to Lake Tänavjärv (Kadastik, 2004). By 6500 cal yr BP the delta plain had partly emerged, becoming subject to wave erosion and wind deflation, and forming a beach ridge/dune landscape to the north and northwest of Lake Tänavjärv (Fig. 4A). Due to the shallow sea, the isolation of Lake Tänavjärv was a rather short-lived process: by $6000 \mathrm{cal}$ yr BP a lagoon with a passage in the south was formed, surrounded by beach ridges in the north and southeast and by a reworked esker ridge or spit in the west and southwest (Fig. 4B). According to the palaeoreconstruction, Lake Tänavjärv was fully isolated by 5400 cal yr BP (Fig. 4C). These results are consistent with the conclusions made earlier on the basis of 

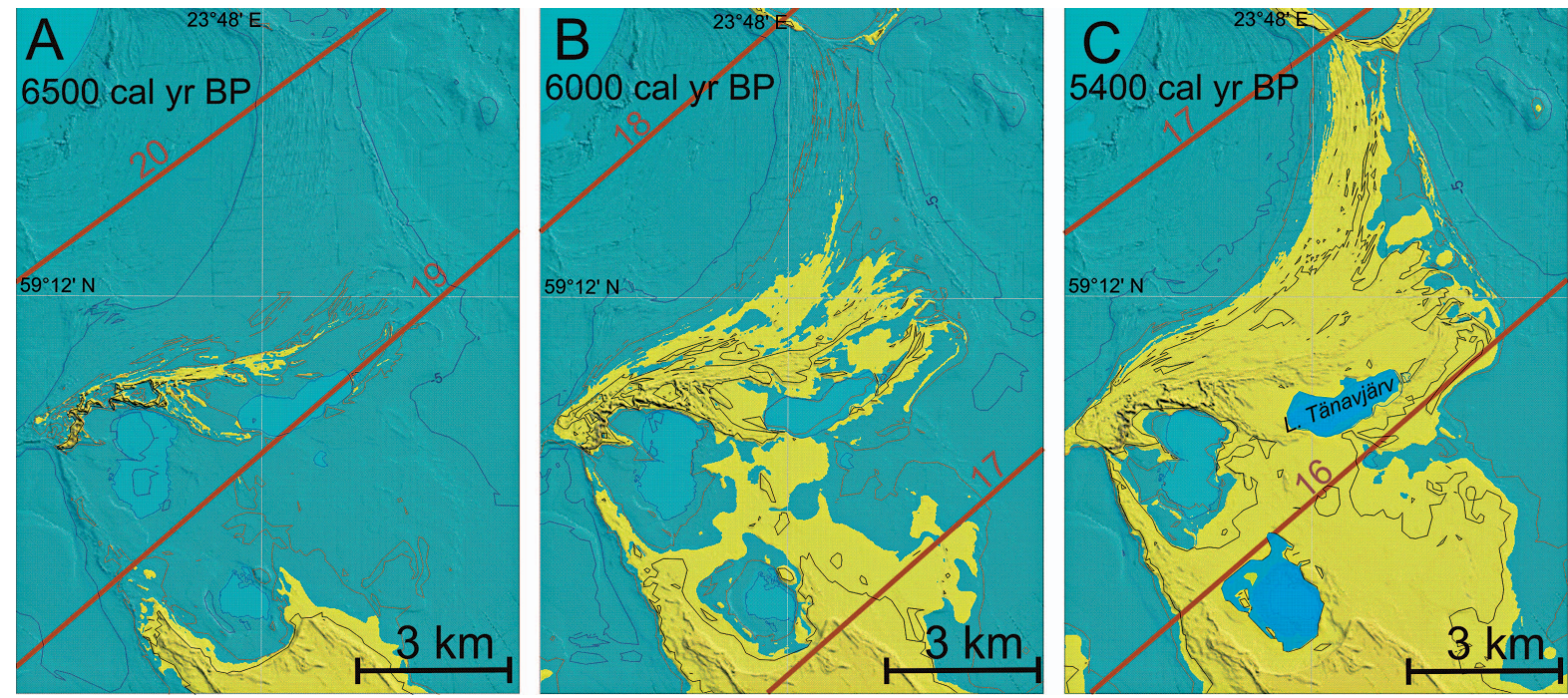

Fig. 4. Palaeogeographic maps of the Tänavjärv area for the time windows of 6500 (A), 6000 (B) and 5400 (C) cal yr BP. Modelled water level surface isobases are indicated by brown lines together with altitudes in meters a.s.l. The shoreline is shown with deviation $\pm 1 \mathrm{~m}$ (black line $+1 \mathrm{~m}$, brown line $-1 \mathrm{~m}$ ). Blue line corresponds to the $5 \mathrm{~m}$ water depth. The reconstructions are compiled with LIDAR elevation data (Estonian Land Board) to visualize the present day land (yellow) and sea (blue) area.

pollen analyses, according to which sediments corresponding to the isolation were deposited in the second half of the Atlantic period (Saarse et al., 1989).

During the Litorina Sea transgression, a spit was formed in the area to the east of Lake Klooga, isolating a small lagoon. In the surroundings of Niitvälja, a costal lake was formed (Fig. 5A), where gyttja deposited until 8390 $\pm 70 \mathrm{cal} \mathrm{yr} \mathrm{BP} \mathrm{(Table} \mathrm{2),}$ later buried by deposits of marine and terrestrial deposits. At $5000 \mathrm{cal} \mathrm{yr} \mathrm{BP,} \mathrm{a} \mathrm{beach} \mathrm{ridge} \mathrm{system}$ developed to the east of the lake, while a tombolo started to form north of the lake, closing the northern connection with the sea by $4000 \mathrm{cal} \mathrm{yr}$ BP (Fig. 5C), and only a small passage in the west through the Vasalemma River valley provided the connection with the sea. Obviously, the lake level was slightly higher than the sea level and the passage functioned as a drainage canal of the lake, because the diatom record confirms an isolation around 4200 cal yr BP, which compared to Lake Tänavjärv was tardy due to the depth of the surrounding sea. Therefore, the isolation of Lake Klooga was contingent not only on the land uplift, but also on the development of different beach formations.
At $7800 \mathrm{cal}$ yr BP the coastline of northern Estonia mostly followed the klint escarpment (Fig. 6A) and both Lohja and Käsmu lakes acted as offshore basins with small nearby islets. They maintained their broad connection with the sea until $4000 \mathrm{cal}$ yr BP (Grudzinska et al., 2012). At 3000 cal yr BP, semi-closed lagoons formed in the place of Lohja and Käsmu lakes, with narrow passages between the sea and the lagoons. Lohja and Käsmu lakes became isolated by $2200 \mathrm{cal} \mathrm{yr} \mathrm{BP}$ and 1800 cal yr BP, respectively, and developed into isolated coastal lakes (Fig. 6). This evidence confirms that Lake Käsmu isolated about 1000 years earlier than previously suggested (Kessel et al., 1986). The isolation history of Lake Lohja in the rump of the klint bay was mainly determined by the post-glacial relief-forming processes, primarily by the beach ridges and dunes. The isolation of Lake Käsmu on the drumlin-like peninsula (Karukäpp, 2004) was also controlled by glacial formations, primarily by a buried esker ridge to the west of the lake. LIDAR maps show that the surface of these drumlin-like forms was jointed by several esker-like ridges orientated to the ice flow direction as can be seen on the Pärispea Peninsula (Fig. 6). 

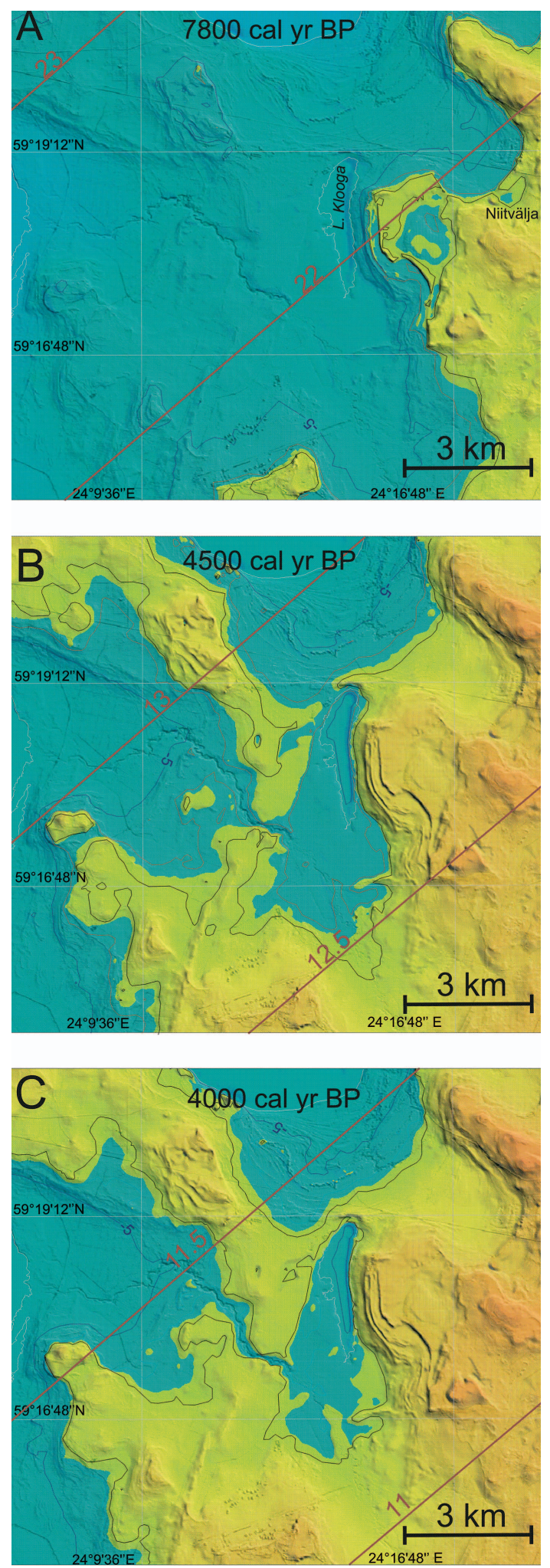

Fig. 5. Palaeogeographic maps of the Klooga area for the time windows of 7800 (A), 4500 (B) and 4000 (C) cal yr BP. For legend explanations see Fig. 4.
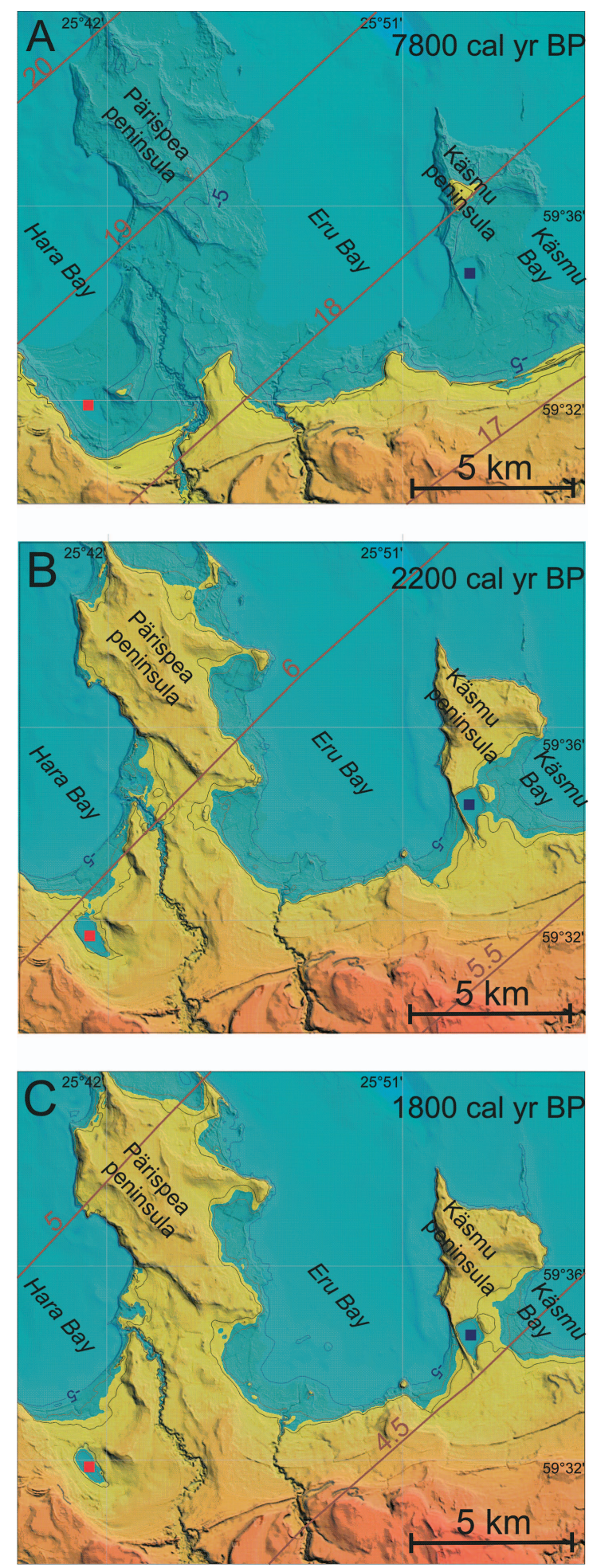

Fig. 6. Palaeogeographic maps of the Lohja and Käsmu area for the time windows of 7800 (A), 2200 (B) and 1800 cal yr BP (C). For legend explanations see Fig. 4. Lake Lohja is shown by a red square and Lake Käsmu by a blue square. 


\subsection{Relative sea level curve}

Despite several studies conducted in northern and western Estonia, the relative sea level curves that are based on both bio- and chronostratigraphical data have not been constructed until only recently. The relative sea level curves for the Tänavjärv, Klooga, Lohja and Käsmu area were compiled, considering the diatom evidence, lithostratigraphy, ${ }^{14} \mathrm{C}$ dates and geomorphological markers. The presented relative sea level curves are regular from the onset of the Litorina Sea regression (Fig. 7), showing smoothly falling sea level from $22 \mathrm{~m}$ a.s.l. down to the present level. The isolation horizon provides regular upwards-younger radiocarbon ages, and biostratigraphic proxies do not show evidence of transgression after 6000 cal yr BP. The smoothly falling relative sea level does not rule out changes in local water level during heavy storms that have been rather frequent over the last century and have caused remarkable damages on the coast (Orviku et al., 2009). In general, the reconstructed sea level curves show a linear trend of sea level lowering that is similar to the reconstructed curves around the Gulf of Botnia (Lindén et al., 2006; Widerlund \& Andres- son, 2011) and the Gulf of Finland (Hyvärinen, 1982; Miettinen, 2002; Miettinen et al., 1999; Saarnisto, 2012), but differs from the previously presented ones concerning the southern coast of the Gulf of Finland (Kents, 1939; Kessel \& Raukas, 1979; Raukas \& Ratas, 1995) and southern Sweden (Berglund et al., 2005) that displayed several water level fluctuations during the Litorina Sea. Based on recent studies, the Litorina Sea transgression peaked about 7800 cal yr BP (Saarse et al., 2010). The amplitude of the transgression was about 3-4 m, which is compatible with studies carried out in southern Finland in areas with the similar isobase of the land uplift (Miettinen, 2002; Miettinen \& Hyvärinen, 1997). Considerably higher magnitude of the Litorina Sea transgression occurred in areas of low uplift, being about $7 \mathrm{~m}$ in the surroundings of Pärnu (Fig. 1; Veski et al., 2005). As the Baltic Sea shorelines are widely distributed in northern and western Estonia, they also provide the possibility to examine the pattern of the uplift which they are indicative of (Smith et al., 2000). While the average apparent uplift today in the Tänavjärv-Klooga area is about $2.2 \mathrm{~mm} \mathrm{yr}^{-1}$ and in Käsmu-Lohja area $2.0 \mathrm{~mm} \mathrm{yr}^{-1}$ (Torim, 2004), then

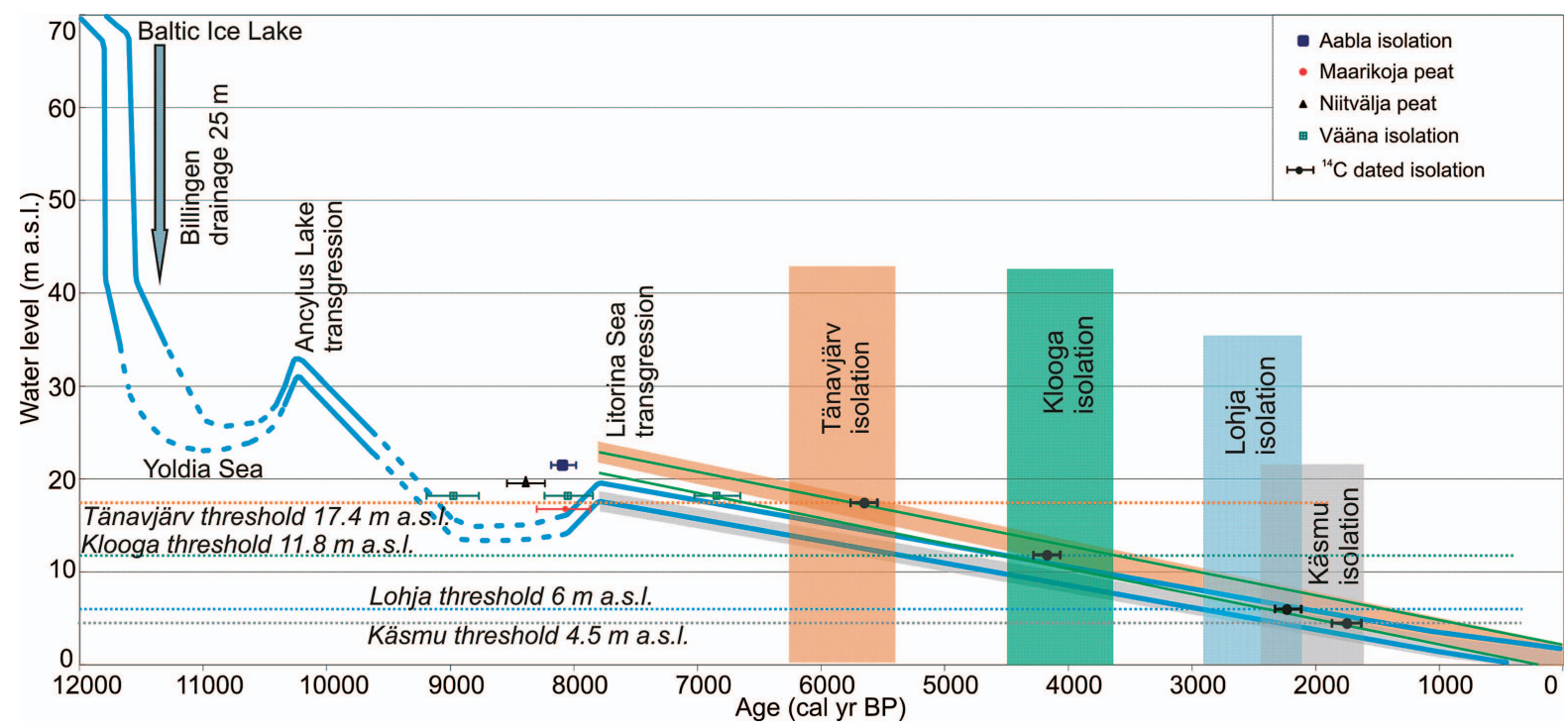

Fig. 7. The relative sea level curves for study areas. Lines mark the modelled possible minimum and maximum water level (green for Lake Klooga, blue for Lake Lohja) and areas mark the modelled possible range of the water level (orange for Lake Tänavjärv and grey for Lake Käsmu). Reconstruction considers errors both in the modelled water levels $\pm 1 \mathrm{~m}$ and in the ages. Boxes in different colours show the isolation age range according to modelled water level. Black circles with error bars indicate the radiocarbon-dated age of the isolation. 
according to our calculations the land uplift rates were higher in the mid-Holocene, 2.8 and $2.4 \mathrm{yr}^{-1}$, respectively, showing a continuous decreasing trend towards the present. If there will not be any rapid rise in the ocean level, the lowering trend of the sea level and apparent uplift in northern Estonia will continue.

\section{Conclusions}

Threshold elevation and marine limit comparison confirmed that the Litorina Sea water reached 22.1 $\mathrm{m}$ a.s.l. at Tänavjärv, $21.9 \mathrm{~m}$ a.s.l. at Klooga, 18.8 $\mathrm{m}$ a.s.l. at Lohja and $17.7 \mathrm{~m}$ a.s.l. at Käsmu in northern Estonia.

In all four sediment records the succession of diatom assemblages marks distinctly the palaeoenvironmental changes induced by glacioisostatic uplift and consecutive relative sea level regression through periods of brackish-water environment, isolation from the sea and subsequent lacustrine conditions.

The final isolation contact of the lakes occurred between 5400 and $1800 \mathrm{cal} \mathrm{yr} \mathrm{BP}$ without notable sea level oscillations during the post-Litorina period.

The isolation of lakes was dependent on the land uplift rate, determined also by the glacial and postglacial relief forms, such as eskers, limestone terraces, beach ridges and dunes.

The relative sea level curves show a land uplift decrease for the last 6000 years and a smoothly falling sea level.

\section{Acknowledgements}

We wish to acknowledge M. Märss for language check. We thank two anonymous reviewers for valuable comments and suggestions. The study was supported by the Estonian Target Financing project SF0140021s12, institutional research funding IUT1-8, ESF Grant 9031 and European Social Fund's Doctoral Studies and Internationalisation Programme DoRa.

\section{References}

Battarbee, R., Jones, V.J., Flower, R.J., Cameron, N.G., Bennion, H., Carvalho, L. \& Juggins, S. 2001. Diatoms. In: Smol, J. P., Birks, H. J. B. \& Last, W. (eds.) Tracking
Environmental Change Using Lake Sediments, Vol. 3: Terrestrial, Algal, and Siliceous Indicators. Kluwer Academic Publishers, Dordrecht, pp. 155-202.

Berglund, B.E., Sandgren, P., Barnekow, L., Hannon, G., Jiang, H., Skog, G. \& Yu, S.-Y. 2005. Early Holocene history of the Baltic Sea, as reflected in coastal sediments in Blekinge, south-eastern Sweden. Quaternary International 130, 111-139.

Bigler, C., Hall, R.I. \& Renberg, I. 2000. A diatom-training set for palaeoclimatic inferences from lakes northern Sweden. Verhandlungen Internationale Vereinigung für Theoretische und Angewandte Limnologie 27, 1-9.

Bradshaw, E.G., Anderson, N.J., Jensen, J.J. \& Jeppesen, E. 2002. Phosphorus dynamics in Danish lakes and the implications for diatom ecology and palaeoecology. Freshwater Biology 47, 1963-1975.

Björck, S. 1995. A review of the history of the Baltic Sea, 13.08.0 ka BP. Quaternary International 27, 19-40.

Bronk Ramsey, C. 2008. Deposition models for chronological records. Quaternary Science Reviews 27, 42-60.

Bronk Ramsey, C. 2009. Bayesian analysis of radiocarbon dates. Radiocarbon 51, 337-360.

Dixit, S.S. \& Dickman, M. 1986. Correlation of surface sediment diatoms with the present lake $\mathrm{pH}$ in 28 Algoma lakes, Ontario, Canada. Hydrobiologia 131, 133-143.

Eronen, M., Glückert, G., Hatakka, L., van de Plassche, O., van der Plicht, J. \& Rantala, P. 2001. Rates of Holocene isostatic uplift and relative sea-level lowering of the Baltic in SW Finland based on studies of isolation contacts. Boreas 30, 17-30.

Gibson, C.E., Anderson, N.J., Haworth, E.Y. 2003. Aulacoseira subarctica: taxonomy, physiology, ecology and paleoecology. European Journal of Phycology 38, 83-101.

Grimm, E. 2007. Tilia Version 1.0.1. Illinois State Museum, Research and Collections Center, Springfield.

Grudzinska, I., Saarse, L., Vassiljev, J., Heinsalu, A. \& Veski, S. 2012. A palaeocoastline reconstruction for the Käsmu and Pärispea Peninsulas (northern Estonia) over the last 4000 years. Estonian Journal of Earth Sciences 61, 307-316.

Hedenström, A. \& Possnert, G. 2001. Reservoir ages in Baltic Sea sediment - a case study of an isolation sequence from the Litorina Sea stage. Quaternary Science Reviews 20, 1779-1785.

Heinsalu, A. \& Veski, S. 2007. The history of the Yoldia Sea in northern Estonia: palaeoenvironmental conditions and climatic oscillations. Geological Quarterly 51, 295-306.

Hyvärinen, H. 1982. Interpretation of stratigraphical evidence of sea-level history: a Litorina site near Helsinki, southern Finland. Annales Academiae Scientiarum Fennicae, A III 134, 139-149.

Kadastik, E. 2004. Upper-Pleistocene Stratigraphy and Deglaciation History in Northwestern Estonia. Dissertations Geologicae Universitatis Tartuensis XV. PhD Dissertation. Tartu University Press, Tartu, 1-128. 
Kadastik, E. \& Ploom, K. 2000. Pleistocene deposits and deglaciation of the Nova-Padise area (NW Estonia). Bulletin of the Geological Survey of Estonia 9/1, 4-10.

Kangur, M. 2005. Disturbances and vegetation patchiness reflected in pollen and charcoal profiles from lacustrine sediments. Dissertations on Natural Sciences 12, Tallinn University, Tallinn, 1-134.

Karukäpp, R. 2004. Late-glacial ice streams of the southeastern sector of the Scandinavian Ice Sheet and the asymmetry of its landforms. Baltica 17, 41-48.

Kents, P. 1939. Postglacial shore displacement changes of the Baltic Sea in Estonia on the example of Kõpu Peninsula. Manuscript in Estonian State Archives. Tallinn, 62 p. (in Estonian)

Kessel, H. \& Linkrus, E. 1979. Ancient coastal lakes and coastal formations in the western part of Lahemaa. In: Raukas, A. (ed.) Eesti NSV saarkôrgustike ja järvenõgude kujunemine, Valgus, Tallinn, pp. 104-117. (in Estonian with English summary)

Kessel, H. \& Raukas, A. 1968. The deposits of Ancylus Lake and Litorina Sea in Estonia. Valgus, Tallinn, 135 p. (in Russian with English summary)

Kessel, H. \& Raukas, A. 1979. The Quaternary history of the Baltic. Estonia. In: Gudelis, V. \& Königsson, L.-K. (eds.) The Quaternary history of the Baltic. Acta Universitatis Upsaliensis, Uppsala, pp. 127-146.

Kessel, H., Saarse, L. \& Vishnevskaya, E. 1986. The development of coastal Lake Käsmu (North Estonia). Proceedings of the Academy of Sciences of the Estonian SSR 35, 83- 88. (in Russian with English summary)

Krammer, K. \& Lange-Bertalot, H. 1986. Bacillariophyaceae 1. Teil Naviculaceae. In: Ettl, H., Gerloff, J., Heying, H. \& Mollenhauser, D. (eds.) Süsswasserflora von Mitteleuropa 2/1. Gustav Fisher Verlag, Stuttgart, 876 p.

Krammer, K. \& Lange-Bertalot, H. 1988. Bacillariophyaceae 2. Teil Bacillariaceae, Epithemiaceae, Surirellaceae. In: Ettl, H., Gerloff, J., Heying, H. \& Mollenhauser, D. (eds.) Süsswasserflora von Mitteleuropa 2/2. Gustav Fisher Verlag, Stuttgart, $596 \mathrm{p}$.

Krammer, K. \& Lange-Bertalot, H. 1991a. Bacillariophyaceae 3. Teil Centrales, Fragilariceae, Eunotiaceae. In: Ettl, H., Gerloff, J., Heying, H. \& Mollenhauser, D. (eds.) Süsswasserflora von Mitteleuropa 2/3. Gustav Fisher Verlag, Stuttgart, 576 p.

Krammer, K. \& Lange-Bertalot, H. 1991b. Bacillariophyaceae 4. Teil Achnanthaceae. In: Ettl, H., Gerloff, J., Heying, H. \& Mollenhauser, D. (eds.) Süsswasserflora von Mitteleuropa 2/4. Gustav Fisher Verlag, Stuttgart, 437 p.

Lindén, M., Möller, P., Björck, S. \& Sandgren, P. 2006. Holocene shore displacement and deglaciation chronology in Norrbotten, Sweden. Boreas 35, 1-22.

Lougheed, B.C., Snowball, I., Moros, M., Kabel, K., Muscheler, R., Virtasalo, J.J. \& Wacker, L. 2012. Using an independent geochronology based on palaeomagnetic secular variation (PSV) and atmospheric $\mathrm{Pb}$ deposition to date Baltic Sea sediments and infer ${ }^{14} \mathrm{C}$ reservoir age. Quaternary Science Reviews 42, 43-58.

Lunkka, J.-P., Putkinen, N. \& Miettinen, A. 2012. Shoreline displacement in the Belomorsk area, NW Russia during the Younger Dryas Stadial. Quaternary Science Reviews 37, 26-37.

Miettinen, A. 2002. Relative sea level changes in the eastern part of the Gulf of Finland during the last 8000 years. Annales Academiae Scientiarum Fennicae, GeologicaGeographica 162, 1-102.

Miettinen, A., Eronen, M. \& Hyvärinen, H. 1999. Land uplift and relative sea-level changes in the Loviisa area, southeastern Finland. Posiva Report 99-28, Posiva Oy, 26 pp.

Miettinen, A. \& Hyvärinen, H. 1997. Stratigraphical evidence of Baltic water level changes between 8 and $6 \mathrm{ka} \mathrm{BP}$ in a small lake basin on the coast of the Gulf of Finland. Bulletin of the Geological Society of Finland 69, 43-53.

Miettinen, A., Jansson, H., Alenius, T. \& Haggrén, G. 2007. Late Holocene sea-level changes along the southern coast of Finland, Baltic Sea. Marine Geology 242, 27-38.

Mörner, N.-A. 1979. The Fennoscandian uplift and Late Cenozoic in geodynamics: geological evidence. GeoJournal 3, 287-318.

Orviku, K., Suursaar, Ü., Tónisson, H., Kullas, T. Rivis, R. \& Kont, A. 2009. Coastal changes in Saaremaa Island, Estonia, caused by winter storms in 1999, 2001, 2005 and 2007. Journal of Coastal Research 56, 1651-1655.

Punning, J.-M., Rajamäe, R., Joers, K. \& Putnik, H. 1980. Tallinn radiocarbon dates VI. Radiocarbon 22, 91-98.

Ramsay W. 1929. Niveauverschiebungen, Eisgestaute Seen und Rezession des Inlandeises in Estland. Fennia 52, 1-48.

Raukas, A. \& Ratas, U. 1995. Holocene evolution and palaeoenvironmental conditions of Hiiumaa Island, northwestern Estonia. PACT 50, 167-174.

Reimer, P.J., Baillie, M.G.L., Bard, E., Bayliss, A., Beck, J.W., Blackwell, P.G., Bronk Ramsey, C., Buck, C.E., Burr, G.S., Edwards, R.L., Friedrich, M., Groots, P.M., Guilderson, T.P., Hajdas, I., Heaton, T.J., Hogg, A.G., Hughen, K.A., Kaiser, K.F., Kromer, B., McCormac, F.G., Manning, S.W., Reimer, R.W., Richards, D.A., Southon, J.R., Talamo, S., Turney, C.S.M., van der Plicht, J. \& Weyhenmeyer, C.E. 2009. IntCal09 and Marine09 radiocarbon age calibration curves, 0-50,000 years cal BP. Radiocarbon 51, 11111150 .

Riikoja, H. 1934. List of Estonian lakes. Looduseuurijate Seltsi Aruanded XLI, 1-192. (in Estonian)

Risberg, J., Alm, G. \& Goslar, T. 2005. Variable isostatic uplift patterns during the Holocene in southeast Sweden, based on high-resolution AMS radiocarbon datings of lake isolations. The Holocene 15, 847-857.

Rosentau, A., Vassiljev, J., Hang, T., Saarse, L. \& Kalm, V. 2009. Development of the Baltic Ice Lake in the eastern Baltic. 
Quaternary International 206, 16-23.

Rosentau, A., Veski, S., Krïska, A., Aunap, R., Vassiljev, J., Saarse, L., Hang, T., Heinsalu, A. \& Oja T. 2011. Palaeogeographic model for the SW Estonian coastal zone of the Baltic Sea. In: Harff, J., Björck, S. \& Hoth, P. (eds.) The Baltic Sea Basin. Springer-Verlag, Berlin Heidelberg, pp. 165-188.

Saarnisto, M. 2012. Late Holocene land uplift/neotectonics on the island of Valamo (Valaam), Lake Ladoga, NW Russia. Quaternary International 260, 143-152.

Saarse, L., Heinsalu, A., Poska, A., Veski, S. \& Rajamäe, R. 1999. Palaeoecology and human impact in the vicinity of Lake Kahala, North Estonia. PACT 57, 373-403.

Saarse, L. Vassiljev, J., Rosentau, A. \& Miidel, A. 2007. Reconstructed late glacial shore displacement in Estonia. Baltica 20, 35-45.

Saarse, L., Heinsalu, A. \& Veski, S. 2009. Litorina Sea sediments of ancient Vääna Lagoon, northwestern Estonia. Estonian Journal of Earth Sciences 58, 85-93.

Saarse, L., Vassiljev, J. \& Heinsalu, A. 2010. Reconstruction of the land-sea changes on the Juminda peninsula, North Estonia, during the last 10300 years. Baltica 23, 117126.

Saarse, L., Vishnevskaya, E., Sarv, A. \& Rajamäe, R. 1989. The evolution of Lake Tänavjärv. Proceedings of the Estonian Academy of Sciences, Geology 38, 167-175. (in Russian with English summary)

Sandgren, P., Subetto, D.A., Berglund, B.E., Davydova, N.N. \& Savelieva, L.A. 2004. Mid-Holocene Littorina Sea transgressions based on stratigraphic studies in coastal lakes of NW Russia. GFF 126, 363-380.

Saros, J.E. \& Fritz, S.C. 2000. Nutrients as a link between ionic concentration/composition and diatom distributions in saline lakes. Journal of Paleolimnology 23, 449-453.

Smith, D.E., Cullingford, R.A. \& Firth, C.R. 2000. Pattern of isostatic land uplift during the Holocene: evidence from mainland Scotland. The Holocene, 489-501.

Snoeijs, P. 1993. Intercalibration and distribution of diatom species in the Baltic Sea 1. Opulus Press, Uppsala, 129 p.

Snoeijs, P. \& Balashova, J. 1998. Intercalibration and distribution of diatom species in the Baltic Sea 5. Opulus Press, Uppsala, 144 p.
Snoeijs, P. \& Kasperovičien, J. 1996. Intercalibration and distribution of diatom species in the Baltic Sea 4. Opulus Press, Uppsala, 126 p.

Snoeijs, P. \& Potapova, M. 1995. Intercalibration and distribution of diatom species in the Baltic Sea 3. Opulus Press, Uppsala, 126 p.

Snoeijs, P. \& Vilbaste, S. 1994. Intercalibration and distribution of diatom species in the Baltic Sea 2. Opulus Press, Uppsala, $126 \mathrm{p}$.

Tammekann, A. 1940. The Baltic Clint. A Geomorphological Study. Publicationes Instituti Universitatis Tartuensis Geographici 24, 1-103.

Torim, A. 2004. On the land uplift and changes in the coastline of Estonia. Geodeet 28, 57-62. (in Estonian)

Vassiljev, J., Saarse, L. \& Rosentau, A. 2011. Palaeoreconstruction of the Baltic Ice Lake in the Eastern Baltic. In: Harff, J., Björck, S. \& Hoth, P. (eds.) The Baltic Sea Basin. Springer-Verlag, Berlin Heidelberg, pp. 189-202.

Vassiljev, J. \& Saarse, L. 2013. Timing of the Baltic Ice Lake in the eastern Baltic. Bulletin of Geological Society of Finland $85,9-18$.

Veski, S., Heinsalu, A., Klassen, V., Kriiska, A., Lõugas, L., Poska, A. \& Saluäär, U. 2005. Early Holocene coastal settlement and palaeoenvironment on the shore of the Baltic Sea at Pärnu, southwestern Estonia. Quaternary International 130, 75-85.

Weckström, K. \& Juggins, S. 2006. Coastal diatomenvironment relationships from the Gulf of Finland, Baltic Sea. Journal of Phycology 42, 21-35.

Widerlund, A. \& Andersson, P.S. 2011. Late Holocene freshening of the Baltic Sea derived from high-resolution strontium isotope analyse of mollusk shells. Geology 39, 187-190.

Witkowski, A., Lange-Bertalot, H. \& Metzeltin, D. 2000. Diatom Flora of Marine Coasts I. Iconographia Diatomologica 7. A.R.G. Gantner Verlag K.G., Ruggell, Liechtenstein, 925 p.

Yu, S.-Y., Berglund, B.E., Andrén, E. \& Sandgren, P. 2004. Mid-Holocene Baltic Sea transgression along the coast of Blekinge, SE Sweden - ancient lagoons correlated with beach ridges. GFF 126, 257-272. 